ORIGINAL ARTICLE

\title{
Spatiotemporal variation in fire occurrence in the state of Amazonas, Brazil, between 2003 and 2016
}

\author{
Benjamin Leonardo Alves WHITE \\ Universidade Federal de Sergipe, Departamento de Biociências, Av.Vereador Olímpio Grande s/n, Itabaiana, Sergipe, Brazil \\ Corresponding author: white@ufs.br
}

\section{ABSTRACT}

Wildland fires can be responsible for negative impacts on the environment, causing damage to the fauna and flora and increasing the release of greenhouse gases. In the state of Amazonas, wildland fires represent a risk for biodiversity conservation, since more than $95 \%$ of the state is covered by Amazon rainforest, one of the largest and most biodiverse tropical forests of the world. This study aimed to analyze the spatiotemporal variation of fire occurrence from 2003 to 2016 in the state of Amazonas, based on data from the AQUA satellite processed by the Brazilian National Institute for Space Research, using the "Collection 5" detection algorithm. The correlation between fire incidence versus anthropogenic and climatic variables was also tested. A significant uptrend was observed in the number of hot spots recorded over the years. About $83 \%$ of the wildland fires occurred during the months of August, September and October. The variables that correlated significantly with the number of hot spots for each municipality were deforested area, pasture area, agricultural area, municipality area and mean annual rainfall. The municipality with the highest number of hot spots detected was Lábrea, while Careiro da Várzea presented the highest incidence per $\mathrm{km}^{2}$. The southern and eastern regions of the state were the areas most affected by fire during the analyzed period. The results from this study emphasize the need for implementation of public policies aimed to reduce deforestation and wildland fires in the state, thus ensuring the conservation of the Amazon rainforest and its biodiversity.

KEYWORDS: hot spots; fire prevention; wildfire; remote sensing

\section{Variação espaço-temporal da ocorrência de queimadas e incêndios florestais no estado do Amazonas, Brasil, entre 2003 e 2016}

\section{RESUMO}

As queimadas controladas e incêndios florestais podem ser responsáveis por impactos negativos ao meio ambiente, ocasionando danos à fauna e flora e contribuindo para a liberaçấo de gases na atmosfera responsáveis pelo efeito estufa. $\mathrm{O}$ fogo no Amazonas representa um grande risco para a preservação da biodiversidade, já que mais de $95 \%$ da área do estado é recoberta por floresta amazônica, uma das maiores florestas tropicais do mundo. Este trabalho teve por objetivo analisar a variação espaço-temporal dos focos de calor registrados de 2003 a 2016 no estado do Amazonas, com base em dados obtidos através do satélite AQUA e processados pelo INPE, utilizando o algoritmo de detecçáo "Collection 5". Os dados de focos de calor foram correlacionados com variáveis antropogênicas e climáticas. Foi observada uma tendência significativa de alta nos registros de focos de calor ao longo dos anos. Cerca de 83\% das detecçóes ocorreram nos meses de Agosto, Setembro e Outubro. As variáveis área desmatada, área de pastagem, área agrícola, área do município e precipitação média anual apresentaram correlação significativa com o número de focos de calor para cada município. O município com maior registro de focos de calor foi Lábrea, enquanto Careiro da Várzea apresentou a maior incidência por área. Os resultados obtidos ressaltam a necessidade de implementação de políticas públicas que visem a reduçâo do desmatamento e dos incêndios florestais no estado, garantindo a preservação da floresta amazônica e sua biodiversidade.

PALAVRAS-CHAVE: focos de calor; prevenção contra o fogo; incêndios florestais; sensoriamento remoto 


\section{INTRODUCTION}

Wildland fires are any non-structure fire that occurs in vegetation or natural fuels and include prescribed (controlled) burns and wildfires (uncontrolled) (NWCG 2017). They can be a major threat to the preservation of biodiversity, causing impact on the fauna and flora, and contributing, indirectly, with environmental degradation (Soares and Batista 2007). Moreover, the smoke often causes respiratory complications and represents, in some locations, a public health issue (Arbex et al. 2004; Shlisky et al. 2009).

In the state of Amazonas, the use of fire is cultural and difficult to replace (Cabral et al. 2013), being generally used in an irregular manner, without authorization from the responsible environmental agency, the Amazonas Environmental Protection Institute (IPAAM). The use of fire, with or without the use of controlled burning techniques, is prohibited in August, September and October in all the state (IPAAM 2010). Between November and June, prescribed burns can be carried out exclusively when authorized by the agency.

The detection of controlled and uncontrolled wildland fire via satellite began in the 1980s (Wang et al. 2012). Images generated by the thermal and infrared sensors installed in the satellites are sent to a control center and processed through a detection algorithm (Batista 2004; Wang et al. 2012). The use of an efficient algorithm is essential to distinguish fire in vegetation from other heat sources generating a low number of false positives (INPE 2017). It is important to mention that satellite imagery cannot differentiate unmanaged and uncontrolled wildfires from controlled burns (Goldammer and Mutch 2001).

In Brazil, the Weather and Climate Studies Research Center (CPTEC) of the National Institute for Space Research (INPE) generates and provides information on the occurrence of active fires (hot spots) based on satellite data. Among all images received by INPE from various satellites in operation (NOAA-15, NOAA-18, NOAA-19, METOP-B, NASA, TERRA, AQUA, NPP-Suomi, GOES-13 and MSG-3), those generated by the AQUA satellite and processed with the "Collection 5" algorithm have been used as reference since 2002 to compose comparable interannual time series that enable long-term trend analyses in regions of interest (White and White 2016, INPE 2017; White 2017).

Wildfires in the state of Amazonas represent a huge risk for biodiversity conservation, since more than $95 \%$ of the state is covered by the Amazon rainforest, one of the largest tropical forest areas of the world (Primack and Rodrigues 2001; GEA 2017). The exact scope of the problem can only be assessed by satellite data, since local fire statistics in many cases are incomplete or misleading. Therefore, this study aimed to analyze the spatiotemporal variation of fire occurrence in the state of Amazonas using data from the AQUA satellite processed by the "Collection 5" algorithm, for the period from 2003 to
2016. The information obtained can be used by conservation agencies for the improvement of fire prevention and suppression activities, and for the development of public policies focused on wildfire prevention and nature conservation.

\section{MATERIAL AND METHODS}

\section{Study area}

Amazonas is the largest Brazilian state, occupying a total area of $1,559,149.074 \mathrm{~km}^{2}$, larger than the size of France, Spain, Sweden and Greece combined (IBGE 2017a). It is located in northern Brazil and is the state with the most preserved and the least deforested portion of Amazon rainforest (SEMA 2017). The climate is equatorial and classified, in most of the state, as "Equatorial rainforest, fully humid" (Af) according to the updated classification of Köppen and Geiger (Kottek et al. 2006).

\section{Datasets}

The records of hot spots in the state of Amazonas for the period $01 / 01 / 2003$ to $12 / 31 / 2016$ were obtained from the INPE Satellite Monitoring Burning Program website, based on data from the AQUA satellite processed through the "Collection 5" algorithm (INPE 2017). The values were quantified for the entire state and grouped by month of occurrence and the municipality in which they were detected.

The following variables that may have a significant influence on the number of hot spots were quantified for each municipality: mean annual temperature; mean annual rainfall; population density; deforested area; agricultural area and pasture area. These variables were chosen due to availability of historical data and because they have been shown to influence with wildland fire occurrence probability (e.g. Oliveira et al. 2004; Gonçalves et al. 2011; Liu et al. 2012; White et al. 2016a; White et al. 2016b; Suryabhagavan et al. 2016; Ajin et al. 2016; White and White 2016).

Data on agricultural area was obtained from IBGE (2017b). Data on deforested area was obtained from INPE's "PRODES" project, which performs satellite monitoring of clearcut deforestation in the Amazon and calculates, yearly deforested area in the region (CGOBT 2017). Data on demographic density for each municipality are based on IBGE $(2017 \mathrm{c})$. All the variables were quantified annually from 2003 to 2016 for each municipality and had their mean value determined.

Data on pasture area were obtained from project “TerraClass" (CRA 2017; Almeida et al. 2016). Data were available for 2004, 2008, 2010, 2012 and 2014. The mean values for each municipality for the period 2003-2016 were extrapolated based on the available data. Mean annual air temperature and rainfall for each municipality were obtained from Climate-Data (2017) based on climate models and data 
measured between 1982 and 2012. It was assumed that the mean values of temperature and rainfall for each municipality during the period 2003 - 2016 were not statistically different from the average values for $1982-2012$.

\section{Wildland fire incidence per municipality}

The state municipalities were grouped according to the classification proposed by White and White (2016) into five frequency classes based on the number of hot spots per area detected by the AQUA satellite during a period of one year (Table 1).

In order to evaluate wildland fire occurrence over representative long-term time periods of climate variation and land-use change, and to avoid interference of small annual fluctuations, the classification of the frequency of wildfire incidence in each municipality was analyzed in two time periods: 2003-2009 and 2010-2016.

\section{Statistical analysis}

Analysis of Variance (ANOVA) and the post-hoc Tukey HDS test were used to test the existence of a significant differences among the number of hot spots recorded in different months of the year. A linear regression was calculated to evaluate the growth trend in number of hot spots throughout the time series. A correlation matrix was constructed with the Pearson (r) correlation coefficients for the several variables analyzed in the study.

Table 1. Frequency of incidence of hot spots detected by the AQUA satellite over one year. The classification follows White and White (2016).

\begin{tabular}{lc}
\hline Frequency class & Number of hot spots detected per year \\
\hline Very Low & None or one hot spot for an area of $601 \mathrm{~km}^{2}$ or more. \\
Low & One hot spot for an area between $301-600 \mathrm{~km}^{2}$. \\
Average & One hot spot for an area between $151-300 \mathrm{~km}^{2}$. \\
High & One hot spot for an area between $76-150 \mathrm{~km}^{2}$. \\
Very High & One hot spot for an area of $75 \mathrm{~km}^{2}$ or less. \\
\hline
\end{tabular}

\section{RESULTS}

A total of 96,884 hot spots were detected by the AQUA satellite in the state of Amazonas between 2003 and 2016, resulting in an average of approximately 6,920 per year. The lowest record was in 2008 (2,717), and the highest in 2015 $(15,170)$. The annual records indicate a significant uptrend in the number of hot spots throughout the time series $\left(\mathrm{r}^{2}=\right.$ $0.50 ; \mathrm{p}<0.01$ ) (Figure 1).

The month with the highest number of hot spots recorded was September, followed by August, October, November, July, December, January, February, March, June, May and April. About 83\% of the hot spots were detected during the months of August, September and October. Less than 1\% of the fires detected occurred during the months of April, May and June. The number of hot spots varied significantly among the months of the year (ANOVA, F = 23.36, $\mathrm{p}<0.01$ ). The Tukey HDS test grouped the months into three groups with significantly different levels of hot spot occurrence (Figure 2).

Hot spots were recorded in all municipalities in the state of Amazonas (Table 2). Lábrea was the municipality with the highest incidence $(13,593)$ and Japurá with the lowest $(106)$.

The municipalities with the highest number of hot spots detected during 2003-2016 presented the largest deforested areas during the same period. Four other independent variables were significantly correlated with the number of hot spots: pasture area, agricultural area, municipality area and mean annual rainfall. Mean annual temperature and demographic density were not significantly correlated with number of hot spots (Table 3).

Apart from Lábrea, eight other municipalities presented a very high incidence of hot spots (Table 4). Proportionally to its area, Careiro da Várzea registered the highest frequency of incidence of hot spots in the state of Amazonas.

In the first seven years of the time series (2003-2009) the predominant wildfire incidence category in the state of

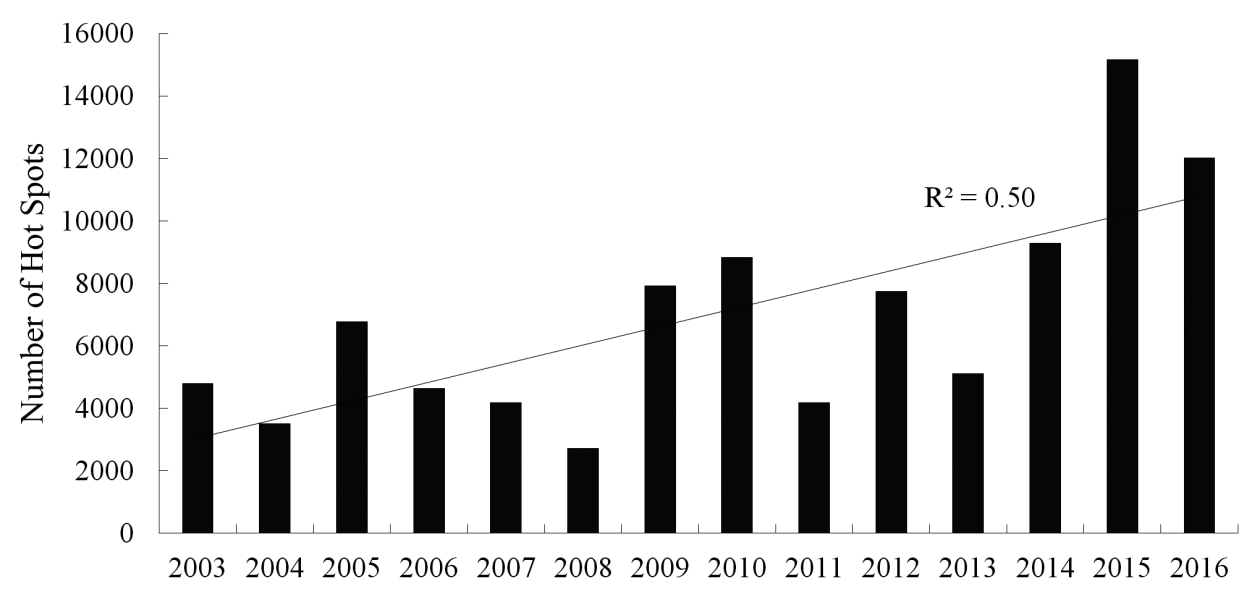

Figure 1. Hot spots detected by the AQUA satellite between 2003 and 2016 in the state of Amazonas, Brazil. The regression line indicates the significant linear upward trend. 


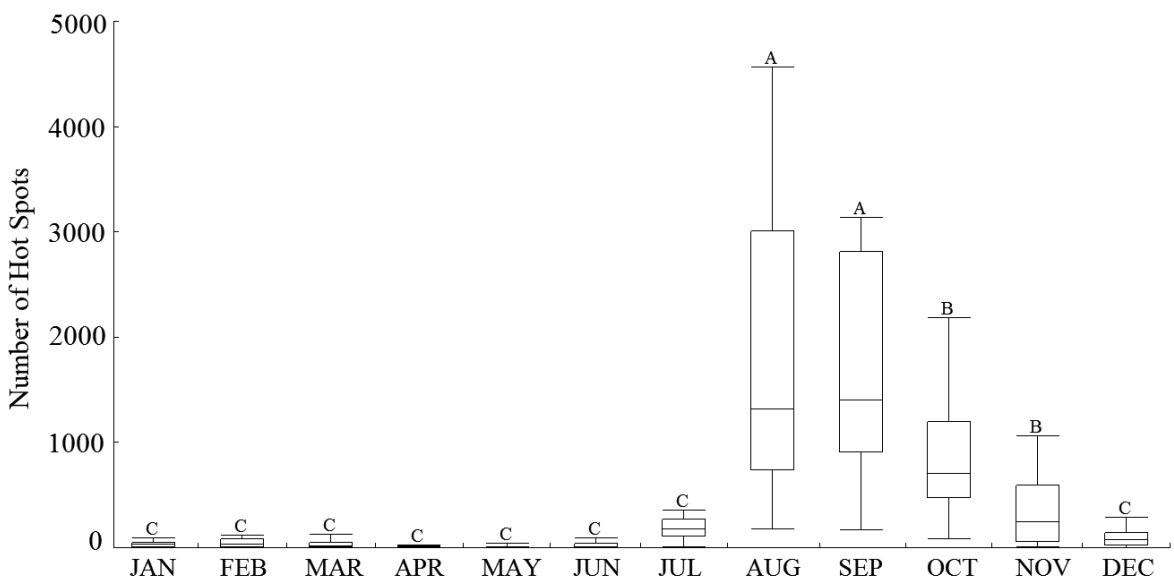

Figure 2. Monthly number of hot spots registered by the AQUA satellite between 2003 and 2016 in the state of Amazonas, Brazil. The line within the box indicates the mean, the box indicates the $25 \%-75 \%$ quartiles, and the bars the 10\% and $90 \%$ quartiles. Letters above the bars indicate significant differences among means.

Table 2. List of municipalities of Amazonas state (Brazil) and their number of detected hot spots (HS); mean annual hot spots; area; area divided by mean annual hot spot (HS density); hot spot frequency of incidence; deforested area; agricultural area; population size; demographic density; mean annual temperature and mean annual rainfall. Municipalities are grouped in descending order of mean annual hot spot density. The first column indicates the identification code of each municipality in Figure 3 .

\begin{tabular}{|c|c|c|c|c|c|c|c|c|c|c|c|c|}
\hline $\begin{array}{l}\text { Code / } \\
\text { Rank }\end{array}$ & Municipality & $H S^{*}$ & $\begin{array}{c}\text { Mean } \\
\text { annual } \\
\text { HS }\end{array}$ & $\begin{array}{c}\text { Municipality } \\
\text { area }\left(\mathrm{km}^{2}\right)\end{array}$ & $\begin{array}{c}\text { Mean } \\
\text { annual HS } \\
\text { density } \\
\left(\mathrm{km}^{2} / \mathrm{HS}\right)\end{array}$ & $\begin{array}{l}\text { HS frequency } \\
\text { of incidence }\end{array}$ & $\begin{array}{c}\text { Deforested } \\
\text { area } \\
\left(\mathrm{km}^{2}\right)^{* * * *}\end{array}$ & $\begin{array}{l}\text { Agricultural } \\
\text { area }\left(\mathrm{km}^{2}\right)^{+}\end{array}$ & $\begin{array}{l}\text { Pasture } \\
\text { area } \\
\left(\mathrm{km}^{2}\right)^{++}\end{array}$ & $\begin{array}{c}\text { Demographic } \\
\text { density (hab/ } \\
\left.\mathrm{km}^{2}\right)^{+++}\end{array}$ & $\begin{array}{l}\text { Mean annual } \\
\text { temperature } \\
\left(^{\circ} \mathrm{C}\right)^{++++}\end{array}$ & $\begin{array}{c}\text { Mean } \\
\text { annual } \\
\text { rainfall } \\
(\mathrm{mm})^{++++} \\
\end{array}$ \\
\hline 1 & $\begin{array}{l}\text { Careiro da } \\
\text { Várzea }\end{array}$ & 1100 & 79 & 2631.1 & 33.49 & Very high & 9.1 & 17.97 & 3.39 & 8.74 & 27.4 & 2166 \\
\hline 2 & Boca do Acre & 7920 & 566 & 22348.9 & 39.51 & Very high & 60 & 6.10 & 2.84 & 1.38 & 25.8 & 2039 \\
\hline 3 & Autazes & 2599 & 186 & 7599.3 & 40.94 & Very high & 18 & 10.91 & 3.40 & 4.26 & 27.1 & 2230 \\
\hline 4 & $\begin{array}{l}\text { Boa Vista do } \\
\text { Ramos }\end{array}$ & 712 & 51 & 2586.8 & 50.86 & Very high & 0.9 & 7.71 & 9.37 & 5.69 & 27.3 & 2249 \\
\hline 5 & Barreirinha & 1469 & 105 & 5750.5 & 54.80 & Very high & 5.2 & 90.93 & 891.83 & 4.88 & 27.6 & 2334 \\
\hline 6 & Parintins & 1471 & 105 & 5952.3 & 56.65 & Very high & 4 & 7.83 & 0.49 & 18.06 & 27.8 & 2257 \\
\hline 7 & Careiro & 1477 & 106 & 6091.5 & 57.74 & Very high & 4.9 & 35.35 & 314.33 & 5.16 & 27.2 & 2171 \\
\hline 8 & Manaquiri & 846 & 60 & 3975.8 & 65.79 & Very high & 1.2 & 4.38 & 2.97 & 5.36 & 27.3 & 2218 \\
\hline 9 & Lábrea & 13593 & 971 & 68229.0 & 70.27 & Very high & 158 & 13.96 & 127.55 & 0.53 & 26.4 & 2318 \\
\hline 10 & Itacoatiara & 1727 & 123 & 2906.7 & 72.08 & Very high & 13 & 25.13 & 0.80 & 9.90 & 27 & 2220 \\
\hline 11 & Apuí & 9979 & 713 & 2215.0 & 76.10 & High & 92 & 13.48 & 10.51 & 0.35 & 27.3 & 2200 \\
\hline 12 & Alvarães & 1049 & 75 & 8892.0 & 78.90 & High & 3.5 & 10.75 & 8.94 & 2.45 & 26.9 & 2261 \\
\hline 13 & Manicoré & 8422 & 602 & 54239.9 & 80.26 & High & 59 & 36.16 & 1180.34 & 0.95 & 26.1 & 2019 \\
\hline 14 & Urucurituba & 493 & 35 & 7329.2 & 82.54 & High & 0.4 & 29.46 & 23.05 & 5.58 & 27.3 & 2309 \\
\hline 15 & Manacapuru & 1221 & 87 & 48282.5 & 84.04 & High & 5.6 & 17.18 & 4.12 & 11.91 & 26.6 & 2550 \\
\hline 16 & Canutama & 4836 & 345 & 5911.8 & 86.33 & High & 36 & 6.29 & 370.98 & 0.42 & 26.9 & 2645 \\
\hline 17 & Silves & 593 & 42 & 3748.8 & 88.50 & High & 2.2 & 13.64 & 45.41 & 2.35 & 21.7 & 2191 \\
\hline 18 & Iranduba & 335 & 24 & 29819.6 & 92.57 & High & 3.4 & 23.86 & 153.51 & 18.50 & 26.5 & 2440 \\
\hline 19 & $\begin{array}{l}\text { Nova Olinda do } \\
\text { Norte }\end{array}$ & 807 & 58 & 8904.2 & 97.30 & High & 3.5 & 15.57 & 126.12 & 5.66 & 25.4 & 2170 \\
\hline 20 & Guajará & 1196 & 85 & 5608.5 & 104.23 & High & 7.4 & 39.19 & 12.66 & 1.60 & 27.1 & 2241 \\
\hline 21 & Novo Aripuanã & 5220 & 373 & 41191.3 & 110.47 & High & 47 & 20.45 & 5.34 & 0.52 & 26.9 & 2444 \\
\hline 22 & Humaitá & 3853 & 275 & 33071.7 & 120.17 & High & 12 & 16.73 & 73.01 & 1.24 & 26.5 & 2322 \\
\hline 23 & Anamá & 239 & 17 & 2453.9 & 143.74 & High & 0.7 & 28.21 & 77.94 & 3.88 & 27 & 2251 \\
\hline 24 & Envira & 1168 & 83 & 13369.3 & 160.25 & Average & 8.5 & 36.91 & 2.33 & 1.27 & 25.8 & 2497 \\
\hline 25 & Rio Preto da Eva & 507 & 36 & 14105.6 & 160.52 & Average & 3.1 & 20.02 & 209.45 & 4.59 & 27.6 & 2348 \\
\hline 26 & Uarini & 876 & 63 & 25422.2 & 163.75 & Average & 3.1 & 45.45 & 189.43 & 1.20 & 27.1 & 2975 \\
\hline 27 & Nhamundá & 1201 & 86 & 9456.6 & 164.43 & Average & 4 & 11.91 & 68.81 & 1.30 & 27.1 & 2204 \\
\hline 28 & Caapiranga & 800 & 57 & 5813.2 & 165.49 & Average & 1.5 & 21.58 & 54.37 & 1.17 & 27.3 & 2302 \\
\hline 29 & $\begin{array}{l}\text { Presidente } \\
\text { Figueiredo }\end{array}$ & 2131 & 152 & 39988.4 & 167.02 & Average & 10 & 92.11 & 285.50 & 1.08 & 27.2 & 2101 \\
\hline 30 & Maués & 3338 & 238 & 10246.2 & 167.72 & Average & 16 & 9.26 & 9.23 & 1.30 & 26.6 & 3032 \\
\hline 31 & Tefé & 1911 & 137 & 23704.4 & 173.66 & Average & 5.9 & 4.99 & 18.16 & 2.75 & 27 & 2464 \\
\hline 32 & Eirunepé & 873 & 62 & 4231.1 & 253.89 & Average & 2.6 & 2.69 & 0.64 & 1.97 & 27 & 2163 \\
\hline 33 & Itapiranga & 230 & 16 & 15831.6 & 257.55 & Average & 0.8 & 4.73 & 3.03 & 2.07 & 25.8 & 2431 \\
\hline
\end{tabular}


Table 2. Continued.

\begin{tabular}{|c|c|c|c|c|c|c|c|c|c|c|c|c|}
\hline $\begin{array}{l}\text { Code / } \\
\text { Rank }\end{array}$ & Municipality & $H S^{*}$ & $\begin{array}{l}\text { Mean } \\
\text { annual } \\
\text { HS }\end{array}$ & $\begin{array}{l}\text { Municipality } \\
\text { area }\left(\mathrm{km}^{2}\right)\end{array}$ & $\begin{array}{c}\text { Mean } \\
\text { annual HS } \\
\text { density } \\
\left(\mathrm{km}^{2} / \mathrm{HS}\right)\end{array}$ & $\begin{array}{l}\text { HS frequency } \\
\text { of incidence }\end{array}$ & $\begin{array}{c}\text { Deforested } \\
\text { area } \\
\left(\mathrm{km}^{2}\right)^{* * *}\end{array}$ & $\begin{array}{l}\text { Agricultural } \\
\text { area }\left(\mathrm{km}^{2}\right)^{+}\end{array}$ & $\begin{array}{l}\text { Pasture } \\
\text { area } \\
\left(\mathrm{km}^{2}\right)^{++}\end{array}$ & $\begin{array}{c}\text { Demographic } \\
\text { density (hab/ } \\
\left.\mathrm{km}^{2}\right)^{+++}\end{array}$ & $\begin{array}{c}\text { Mean annual } \\
\text { temperature } \\
\left({ }^{\circ} \mathrm{C}\right)^{++++}\end{array}$ & $\begin{array}{c}\text { Mean } \\
\text { annual } \\
\text { rainfall } \\
(\mathrm{mm})^{++++}\end{array}$ \\
\hline 34 & Tabatinga & 163 & 12 & 11401.1 & 277.00 & Average & 1.2 & 16.79 & 12.37 & 15.94 & 27.4 & 2145 \\
\hline 35 & Manaus & 543 & 39 & 3225.1 & 293.95 & Average & 3.7 & 45.03 & 1952.51 & 158.97 & 25.9 & 2748 \\
\hline 36 & Ipixuna & 608 & 43 & 10741.0 & 312.37 & Low & 5 & 153.04 & 63.21 & 1.57 & 27.3 & 2105 \\
\hline 37 & $\begin{array}{l}\text { São Sebastião } \\
\text { do Uatumã }\end{array}$ & 430 & 31 & 13565.9 & 349.71 & Low & 2.8 & 20.04 & 28.38 & 0.97 & 25.8 & 2491 \\
\hline 38 & Anori & 211 & 15 & 5795.3 & 384.52 & Low & 0.7 & 23.51 & 64.76 & 2.72 & 26.9 & 2391 \\
\hline 39 & Borba & 1285 & 92 & 44251.2 & 482.11 & Low & 5.2 & 120.42 & 468.04 & 0.81 & 27.1 & 2023 \\
\hline 40 & Amaturá & 124 & 9 & 4758.8 & 537.28 & Low & 0.5 & 11.99 & 1.83 & 2.01 & 25.6 & 2896 \\
\hline 41 & Beruri & 429 & 31 & 17251.2 & 562.98 & Low & 1.9 & 77.84 & 102.47 & 0.89 & 25.8 & 2039 \\
\hline 42 & Coari & 1407 & 101 & 57921.6 & 576.33 & Low & 2.8 & 22.75 & 72.43 & 1.36 & 26.3 & 2290 \\
\hline 43 & Pauini & 924 & 66 & 43263.4 & 655.51 & Very low & 6.3 & 30.62 & 32.10 & 0.42 & 25.8 & 2359 \\
\hline 44 & $\begin{array}{l}\text { Santo Antônio } \\
\text { do Içá }\end{array}$ & 253 & 18 & 12307.8 & 681.06 & Very low & 1 & 5.74 & 7.60 & 2.31 & 25.7 & 3261 \\
\hline 45 & Tonantins & 123 & 9 & 6432.6 & 732.17 & Very low & 0.7 & 24.15 & 247.81 & 2.87 & 25.7 & 3033 \\
\hline 46 & Carauari & 474 & 34 & 25767.3 & 761.06 & Very low & 1.1 & 48.61 & 199.52 & 1.03 & 26.2 & 2587 \\
\hline 47 & Codajás & 340 & 24 & 18711.6 & 770.48 & Very low & 1.4 & 16.01 & 62.05 & 1.18 & 26.7 & 2654 \\
\hline 48 & $\begin{array}{l}\text { Benjamin } \\
\text { Constant }\end{array}$ & 141 & 10 & 8793.4 & 873.10 & Very low & 0.8 & 79.06 & 100.73 & 3.70 & 25.8 & 2751 \\
\hline 49 & Fonte Boa & 174 & 12 & 12110.9 & 974.44 & Very low & 0.9 & 27.50 & 49.64 & 2.18 & 25.6 & 2750 \\
\hline 50 & Urucará & 303 & 22 & 27904.9 & 1289.34 & Very low & 1.6 & 7.18 & 3.97 & 0.67 & 27.4 & 2089 \\
\hline 51 & Tapauá & 959 & 69 & 89324.3 & 1304.00 & Very low & 3.1 & 8.05 & 2.03 & 0.21 & 25.6 & 2460 \\
\hline 52 & Maraã & 181 & 13 & 16910.4 & 1307.99 & Very low & 1.5 & 25.48 & 6.25 & 1.11 & 26.1 & 2857 \\
\hline 53 & Itamarati & 252 & 18 & 25275.9 & 1404.22 & Very low & 1.7 & 11.75 & 3.40 & 0.32 & 25.8 & 2530 \\
\hline 54 & $\begin{array}{l}\text { São Paulo de } \\
\text { Olivença }\end{array}$ & 193 & 14 & 122475.7 & 1432.34 & Very low & 1 & 6.38 & 48.16 & 1.63 & 26.8 & 2339 \\
\hline 55 & Barcelos & 1123 & 80 & 19745.8 & 1526.86 & Very low & 1.5 & 15.49 & 50.43 & 0.23 & 25.6 & 2717 \\
\hline 56 & $\begin{array}{c}\text { São Gabriel da } \\
\text { Cachoeira }\end{array}$ & 861 & 62 & 37771.2 & 1775.36 & Very low & 3.6 & 5.78 & 5.74 & 0.36 & 24.2 & 2504 \\
\hline 57 & Juruá & 151 & 11 & 109184.9 & 1798.71 & Very low & 1.5 & 22.63 & 28.80 & 0.53 & 26.4 & 2909 \\
\hline 58 & Novo Airão & 292 & 21 & 19400.4 & 1810.95 & Very low & 1 & 103.30 & 7.22 & 0.36 & 26.2 & 2937 \\
\hline 59 & Jutaí & 283 & 20 & 69551.9 & 3440.73 & Very low & 1.9 & 10.34 & 2.87 & 0.29 & 25.6 & 2957 \\
\hline 60 & $\begin{array}{l}\text { Santa Isabel do } \\
\text { Rio Negro }\end{array}$ & 205 & 15 & 62846.2 & 4291.94 & Very low & 1.3 & 39.10 & 0.76 & 0.26 & 26.8 & 2497 \\
\hline 61 & $\begin{array}{l}\text { Atalaia do } \\
\text { Norte }\end{array}$ & 154 & 11 & 55791.5 & 6941.36 & Very low & 1.5 & 22.35 & 53.24 & 0.19 & 25.7 & 3101 \\
\hline 62 & Japurá & 106 & 8 & 76355.0 & 7368.69 & Very low & 0.9 & 14.72 & 13.92 & 0.14 & 25.8 & 2709 \\
\hline
\end{tabular}

"Accumulated between 2003 and 2016 (Source: INPE 2017)

"According to White and White (2016)

**A*Annual mean from 2003 to 2016 (Source: PRODES 2017)

+ Annual mean from 2003 to 2016 (Source: IBGE 2017b)

${ }^{++}$Annual mean from data of the years 2004, 2008, 2010, 2012 and 2014 (Source: CRA 2017)

${ }^{+++}$Annual mean from 2003 to 2016 (Source: IBGE 2017c)

${ }^{++++}$Average value based on data from 1982 to 2012 (Source: Climate-Data 2017)

Table 3. Matrix of Pearson correlation coefficients ( $r$ ) between all variables (dependent and independent) used in this study based on the mean value for each municipality of Amazonas state (Brazil). Significant correlations are marked in bold.

\begin{tabular}{|c|c|c|c|c|c|c|c|c|}
\hline & Hot Spots & Municipality area & Pasture area & $\begin{array}{c}\text { Population } \\
\text { density }\end{array}$ & Deforested area & Agricultural area & Rainfall & Temperature \\
\hline Hot Spots & 1.00 & $0.27^{*}$ & $0.92 * *$ & -0.08 & $0.96 * *$ & $0.46 * *$ & $-0.26 *$ & 0.06 \\
\hline Municipality area & & 1.00 & 0.18 & -0.16 & $0.26^{*}$ & 0.03 & 0.15 & -0.13 \\
\hline Pasture area & & & 1.00 & -0.04 & $0.95 * *$ & $0.29 *$ & $-0.26^{*}$ & 0.00 \\
\hline Population density & & & & 1.00 & -0.06 & 0.02 & -0.16 & 0.19 \\
\hline Deforested area & & & & & 1.00 & $0.34 *$ & -0.20 & 0.01 \\
\hline Agricultural area & & & & & & 1.00 & -0.16 & 0.23 \\
\hline Rainfall & & & & & & & 1.00 & $-0.29 *$ \\
\hline Temperature & & & & & & & & 1.00 \\
\hline
\end{tabular}

Note: The source of the data for each variable are described in Table 2.

* Significant at $\mathrm{p}<0.05$

** Significant at $\mathrm{p}<0.01$ 
Amazonas was Very Low (in 26 municipalities, representing $63.71 \%$ of the state area). In the latter seven years of the time series (2010-2016) only 15 municipalities (47.97\% of the state area) had a Very Low incidence frequency. The Very High category, on the other hand, rose from 3 to 18 municipalities from the first to the second period, reflecting the increase of wildland fire activity in the state during the last years (Table 4). The southern and eastern regions of the state showed the highest fire incidence in both periods (Figure 3).
Table 4. Number of municipalities and percentage of the total state area for each of five wildland fire incidence classes for the two study periods. Fire incidence classification according to White and White (2016).

\begin{tabular}{lcc}
\hline \multirow{2}{*}{ Wildland Fire Incidence } & Number of municipalities (\% of total area) \\
\cline { 2 - 3 } & $2003-2009$ & $2010-2016$ \\
\hline Very High & $3(5.93 \%)$ & $18(16.83 \%)$ \\
High & $12(11.86 \%)$ & $12(16.03 \%)$ \\
Average & $13(12.13 \%)$ & $8(4.49 \%)$ \\
Low & $8(6.38 \%)$ & $9(14.68 \%)$ \\
Very Low & $26(63.71 \%)$ & $15(47.97 \%)$ \\
\hline
\end{tabular}
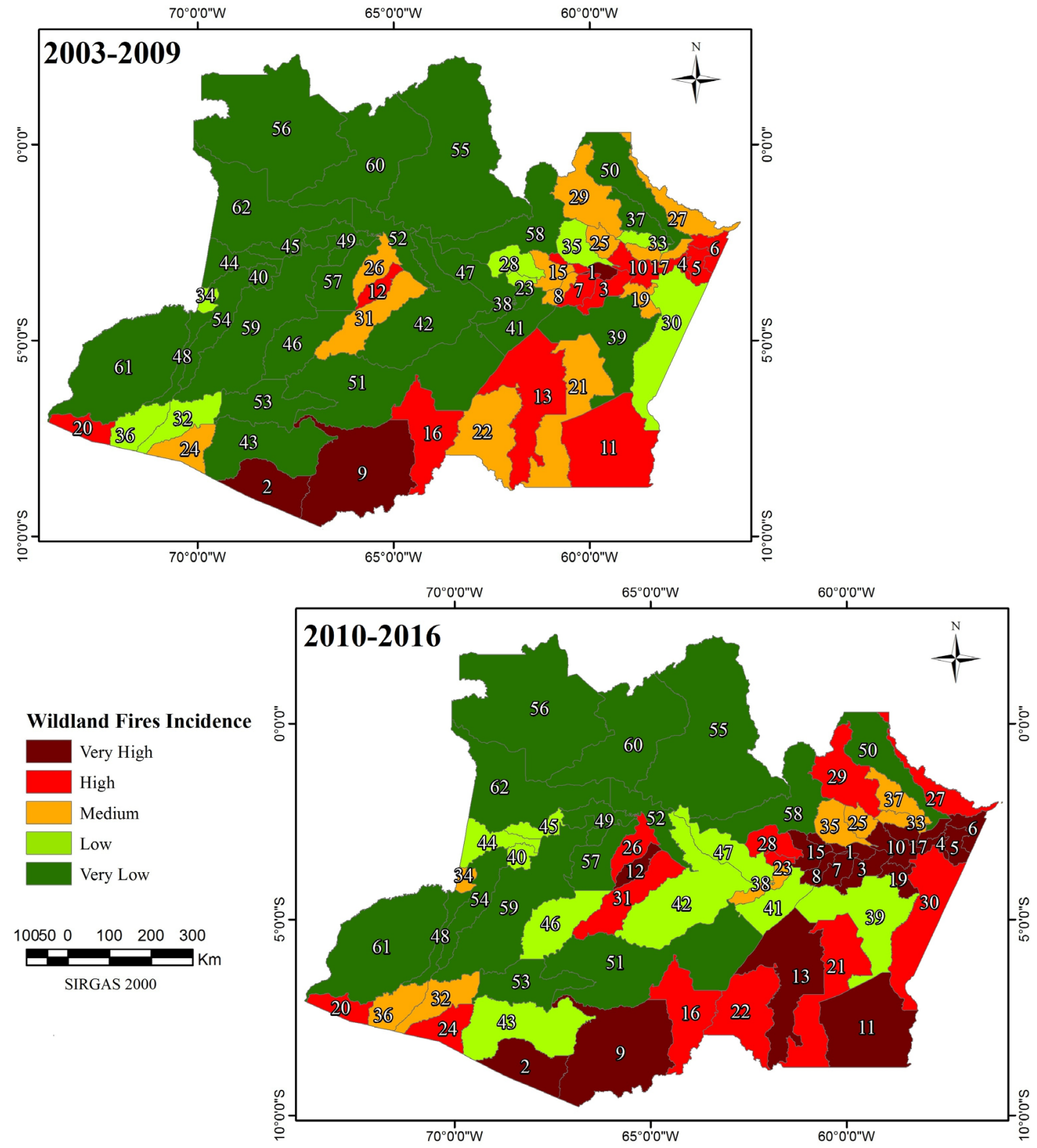

Figure 3. Wildland fire incidence in the municipalities of the state of Amazonas (Brazil) based on the classification proposed by White and White (2016). The first image is based on the mean annual number of hot spots in the period 2003-2009. The second is based on the mean annual number of hot spots in the period $2010-2016$. Municipalities are indicated by numbers with correspondence in Table 2. This figure is in color in the electronic version. 


\section{DISCUSSION}

Although the use of satellites for detecting wildland fires has the advantage of wide range and access to remote areas, resolution limitations of satellites equipped with Moderate Resolution Imaging Spectroradiometer (MODIS) sensor, as in AQUA, prevent the detection of small wildland fires with front line width below $30 \mathrm{~m}$ (INPE 2017). Additionally, satellitebased fire detection may also be restricted when fires started and ended during the interval between the satellite passage, by the presence of dense clouds above the burning area, surface fire under closed canopy vegetation, and fire on mountainsides opposite to the satellite observation path (Setzer et al. 1992; Pereira et al. 2012; INPE 2017). Therefore, the number of wildland fires recorded in this study is likely underestimated.

The highest number of hot spots in the months of August and September follows the pattern observed in most of South America (Bella et al. 2006; White 2017). All South American countries below the equator, with the exception of Chile, present higher fire activity from August to November (White 2017). Vasconcelos et al. (2013) also estimated that $99 \%$ to 95\% of the wildland fires in the Amazonas state occur from July to March with peaks in August, September and October.

The predominant climate in Amazonas is equatorial, differing in some aspects from the predominant tropical climates in Brazil (Mendonça and Danni-Oliveira 2007), with temperatures in winter usually higher than in summer, and a very small intra-annual variation. In most of the state, the hottest months are August, September and October (Mendonça and Danni-Oliveira 2007; Climate-Data 2017). In all municipalities annual rainfall is rarely below 2,000 mm, however, during winter, mainly in August and September, monthly precipitation may fall below $50 \mathrm{~mm}$ in some municipalities (Mendonça and Danni-Oliveira 2007; Climate-Data 2017). Due to low rainfall and high temperatures during this period, the fuel load becomes drier and, therefore, susceptible to burning.

The interannual changes in wildland fire occurrence observed in this study are mostly due to human behavior and are probably linked with climate variations caused by global warming and by the El Niño and La Nina phenomenons (Victoria et al. 1998; Jiménez-Muñoz 2016; White 2017). During the last century global warming was responsible for an increase of $0.56^{\circ} \mathrm{C}$ in the mean temperature in the Brazilian Amazon (Victoria et al. 1998). New climate models predict a reduction in rainfall in the Amazon Basin due to changes in sea surface temperature due to global warming (Harris et al. 2008; Dai 2013). The increase in temperature and reduction in rainfall cause a decrease in vegetation moisture content, the most important component that affects the ignition probability and fire behavior (White et al. 2016b).

The El Nińo-Southern Oscillation (ENSO) alters rainfall patterns and intensifies drought in some South American regions. Recent studies proved the relation between ENSO and interannual fire activity (Page et al. 2008; Chen $e t$ al. 2011; Jiménez-Muñoz et al. 2016). The 2015-2016 ENSO was responsible for record-braking high temperatures and extreme drought in the Amazon region (Jiménez-Muñoz et al. 2016). These extreme temperatures and droughts were likely the main factors responsible for the highest incidence of hot spots in 2015 and 2016. On the other hand, La Niña consists of a basinwide cooling of the tropical Pacific Ocean, and thus the cold phase of ENSO, causing an increase in rainfall in some South American regions (Trenberth 1997). The strong La Niña events during 2007 and 2011 (Null 2016) are likely responsible for the reduction of hot spot detection during these years.

Although meteorological and climatic parameters play a key role in the wildland fire occurrence in the state of Amazonas, human behavior is responsible for $99 \%$ of ignition sources, since only $1 \%$ of wildfires in Brazil originate from a natural source, that is lightning (Soares and Batista 2007). Therefore, it is essential to analyze human activities in order to understand better fire occurrence.

Land use is one of the most important variables in determining wildland fire risk. While tropical forests have a low fire risk, agricultural fields and pastures are generally defined as high risk (e.g. Gonçalves et al. 2011; Suryabhagavan et al. 2016; Ajin et al. 2016; White et al. 2016a). In this study, the municipalities with larger deforested areas, pasture areas and agricultural areas had a higher number of hot spots, which was probably related to deforestation for agricultural and livestock expansion (DeFries et al. 2008) and the constant use of fire for land clearing. The large fires related to deforestation are easily detected through remote sensing. Small controlled burns, used for clearing pastures and agricultural areas from weeds and shrubs, can be detected by satellites usually when the frontline is wider than $30 \mathrm{~m}$ (INPE 2017).

Although deforestation rates in the Brazilian Amazon have declined from 2004 to 2014 (CRA 2017), the number of hot spots detected during this period increased. This happens because fire continues to be used after deforestation as a tool for cleaning pastures and agricultural fields (Chen $e t$ al. 2011). Therefore, it is important to consider accumulated deforestation rates and data on land use change when analyzing wildland fire occurrence.

Deforestation of the Amazon may be responsible for an increase in the temperatures and decrease in rainfall throughout the region (Fisch et al. 1997; Alves et al. 1999; Cohen et al. 2007; Correia et al. 2008; Araujo and Ponte 2016; Sumila 2016). This indirect impact, allied with the effects of global warming, increases the rate of climate change over the Amazon region, leaving it drier and, consequently, more prone to burning. The change in the climate, combined with land cover change, is likely the reason why fire has become a 
devastating force in Amazonia in recent years. The expectations for the next years are not good, as the native forest continues to be cleared and global warming effects increase in the region (Dai 2013; Vasconcelos et al. 2013).

The significant correlation of the number of hot spots with the mean annual amount of rainfall was expected, since vegetation moisture content increases with rainfall, making it more difficult to burn (Schroeder and Buck 1970; Soares and Batista 2007; White and Ribeiro 2011; White and White 2016). Although air temperature is also pointed out by several authors as an important factor that positively influence fire occurrence through the drying of the fuel load (e.g. Schroeder and Buck 1970; Soares and Batista 2007; White et al. 2016b), the variation of average annual air temperature among the municipalities was very low and was not significantly correlated with fire occurrence.

Despite the absence of a significant correlation between the number of hot spots and demographic density, the latter variable is constantly cited in the literature as a main factor that positively affects wildland fire incidence (e.g. Oliveira $e t$ al. 2004; Liu et al. 2012; White et al. 2016a; Suryabhagavan et al. 2016; Ajin et al. 2016). Since anthropic activities are responsible for 99\% of wildfires that occur in Brazil (Soares and Batista 2007), and fires in Amazonas state are mainly initiated by humans (Vasconcelos et al. 2013), it could be expected that more densely populated municipalities would be more prone to burnings. However, larger populations are usually concentrated in urbanized areas, with lower density of pastures, agricultural fields and forest areas (White and White 2016).

The map indicating the wildland fire incidence in the municipalities of the state of Amazonas can be an important visual tool to assess the future risk of wildland fire occurrence. In both periods assessed, the municipalities most affected by fire were located in the south and east of the state, confirming that data from past fires can be used to predict areas with higher risk of future fires (White and White 2016). Besides using fire occurrence history, other thematic maps of the road system, land use, rainfall distribution, among other aspects, can be integrated using Geographic Information Systems (GIS), allowing a better interpretation of the factors responsible for wildland fire occurrence (Chuvieco and Salas 1996; Díaz-Delgado et al. 2004; White and White 2016; White et al. 2016a).

\section{CONCLUSIONS}

The incidence of hot spots in the state of Amazonas increased significantly from 2003 to 2016. The expectation that numbers will continue to grow imposes the urgent need for the implementation of public policies aimed to reduce wildland fires in the region, thus ensuring the conservation of the Amazon rainforest and its biodiversity. These public policies should be applied mainly in the southern and eastern municipalities of the state, since deforestation and fire occurrence were more intense in these regions over the study period. The prevention and combat of wildfires should be carried out with greater effort from early August to late October, since more than $80 \%$ of the hot spots were detected during this period of the year. If the Amazon rainforest continues to be replaced by croplands and, mainly, cattle ranching, and no measures are taken to reduce the use of fire as a management tool, the number of wildland fires in the region will continue to grow, increasing the release of carbon dioxide into the atmosphere and putting at risk global climate stability.

\section{ACKNOWLEDGMENTS}

To the Fundação de Apoio à Pesquisa e à Inovação Tecnológica do Estado de Sergipe (FAPITEC/SE) and the Conselho Nacional de Desenvolvimento Científico e Tecnológico (CNPq) for a scholarship and funding, and to Prof. Theodore James White.

\section{REFERENCES}

Almeida, C.A.; Coutinho, A.C.; Esquerdo, J.C.D.M.; Adami, M.; Venturieri, A.; Diniz, C.G.; Dessay, N.; Durieux, L.; Gomes, A.R. 2016. High spatial resolution land use and land cover mapping of the Brazilian Legal Amazon in 2008 using Landsat-5/ TM and MODIS data. Acta Amazonica, 46: 291-302.

Alves, F.S.M.; Fisch, G.; Vendrame, I.F. 1999. Modificaçôes do microclima e regime hidrológico devido ao desmatamento na Amazônia: estudo de um caso em Rondônia (RO), Brasil. Acta Amazonica, 29: 395-409.

Ajin, R.S.; Loghin, A.M.; Jacob, M.K.; Vinod, P.G.; Krishnamurthy, R.R. 2016. The Risk Assessment Study of Potential Forest Fire in Idukki Wildlife Sanctuary using RS and GIS Techniques. International Journal of Advanced Earth Science and Engineering, 5: 308-318.

Araujo, R.C.; Ponte, M.X. 2016. Efeitos do Desmatamento em Larga-Escala na Hidrologia da Bacia do Uraim, Amazônia. Revista Brasileira de Geografia Física, 9: 2390-2404.

Arbex, M.A.; Cançado, J.E.D.; Pereira, L.A.A.; Braga, A.L.F.; Saldiva, P.H.D.N. 2004. Queima de biomassa e efeitos sobre a saúde. Jornal Brasileiro de Pneumologia, 30: 158-75.

Batista, A.C. 2004. Detecção de incêndios florestais por satélites. Floresta, 34: 237-241.

Bella, C.M.; Jobbágy, E.G.; Paruelo, J.M.; Pinnock, S. 2006. Continental fire density patterns in South America. Global Ecology and Biogeography, 15: 192-199.

Cabral, A.L.A.; Moras Filho, L.O.; Borges, L.A.C. 2013. Uso do fogo na agricultura: legislação, impactos ambientais e realidade na Amazônia. Periódico Eletrônico Fórum Ambiental da Alta Paulista, 9: 159-172.

Chen, Y.; Randerson, J.T.; Morton, D.C.; DeFries, R.S.; Collatz, G.J.; Kasibhatla, P.S.; Marlier, M. E. 2011. Forecasting fire season severity in South America using sea surface temperature anomalies. Science, 334: 787-791. 
Chuvieco, E.; Salas, J. 1996. Mapping the spatial distribution of forest fire danger using GIS. International Journal of Geographical Information Science, 10: 333-345.

Climate-Data. 2017. Clima: Amazonas (https://pt.climate-data.org/ region/95/). Accessed on 16/02/2017.

Cohen, J.C.P.; Beltrão, J.D.C.; Gandu, A.W.; Silva, R.R.D. 2007. Influência do desmatamento sobre o ciclo hidrológico na Amazônia. Ciência e Cultura, 59: 36-39.

CGOBT. 2017. Coordenação Geral de Observação da Terra. Projeto PRODES: Monitoramento da Floresta Amazônica Brasileira por satélite (http://www.obt.inpe.br/prodes/index.php). Accessed on $01 / 02 / 2017$.

Correia, F.W.S.; Alvalá, R.C.S.; Manzi, A.O. 2008. Modeling the impacts of land cover change in Amazonia: a regional climate model (RCM) simulation study. Theoretical and Applied Climatology, 93: 225-244.

CRA. 2017. Centro Regional da Amazônia. TerraClass (http://www. inpe.br/cra/projetos_pesquisas/terraclass2014.php) Accessed on $16 / 02 / 2017$

Dai, A. 2013. Increasing drought under global warming in observations and models. Nature Climate Change, 3: 52-58.

DeFries, R.S.; Morton, D.C.; Van Der Werf, G.R.; Giglio, L.; Collatz, G.J.; Randerson, J.T.; Shimabukuro, Y. 2008. Firerelated carbon emissions from land use transitions in southern Amazonia. Geophysical Research Letters, 35: 1-5.

Díaz-Delgado, R.; Lloret, F.; Pons, X. 2004. Spatial patterns of fire occurrence in Catalonia, NE, Spain. Landscape Ecology, 19: $731-745$

Fisch, G.; Lean, J.; Wright, I.R.; Nobre, C.A. 1997. Simulações climáticas do efeito do desmatamento na Região Amazônica: Estudo de um caso em Rondônia. Revista Brasileira de Meteorologia, 12: 33-48.

Goldammer, J.G.; Mutch, R.W. 2001. Global forest fire assessment 1990-2000. Food and Agriculture Organization of the United Nations, Rome, 494p.

GEA. 2017. Governo do Estado do Amazonas. Dados (http:// www.amazonas.am.gov.br/o-amazonas/dados/). Accessed on $16 / 02 / 2017$

Gonçalves, C.N.; Mesquita, F.W.; Lima, N.R.G.; Coslope, L.A.; Lintomen, B.S. 2011. Recorrência dos incêndios e fitossociologia da vegetaçáo em áreas com diferentes regimes de queima no Parque Nacional da Chapada Diamantina. Revista Biodiversidade Brasileira, 1: 161-179.

Harris, P.P.; Huntingford, C.; Cox, P.M. 2008. Amazon Basin climate under global warming: the role of the sea surface temperature. Philosophical Transactions of the Royal Society of London B: Biological Sciences, 363: 1753-1759.

IBGE. 2017a. Instituto Brasileiro de Geografia e Estatística. Área Territorial Brasileira (http://ibge.gov.br/home/geociencias/ areaterritorial/principal.shtm). Accessed on 16/02/2017.

IBGE. 2017b. Instituto Brasileiro de Geografia e Estatística. Produção Agricola Municipal (https://sidra.ibge.gov.br/pesquisa/pam/ tabelas) Accessed on 17/11/2017.
IBGE. 2017c. Instituto Brasileiro de Geografia e Estatística. Estimativas de População - EstimaPop (https://sidra.ibge.gov.br/ pesquisa/estimapop/tabelas). Accessed on 16/11/2017.

INPE. 2017. Instituto Nacional de Pesquisas Espaciais. Programa Queimadas: Monitoramento por Satélites (http://www.inpe.br/ queimadas). Accessed on 10/01/2017.

IPAAM. 2010. Instituto de Proteção Ambiental do Amazonas. Portaria IPAAM n 127 de 17 de Agosto de 2010. Diário Oficial do Estado do Amazonas (DOEAM) de 20 de Agosto de 2010.

Jiménez-Muñoz, J.C.; Mattar, C.; Barichivich, J.; Santamaría-Artigas, A.; Takahashi, K.; Malhi, Y.; Sobrino, J.A.; Van Der Schrier, G. 2016. Record-breaking warming and extreme drought in the Amazon rainforest during the course of El Niño 2015-2016. Scientific Reports, 6: 1-7.

Kottek, M.; Grieser, J.; Beck, C.; Rudolf, B.; Rubel, F. 2006. World map of the Köppen-Geiger climate classification updated. Meteorologische Zeitschrift, 15: 259-263.

Liu, Z.; Yang, J.; Chang, Y.; Weisberg, P.J.; He, H.S. 2012. Spatial patterns and drivers of fire occurrence and its future trend under climate change in a boreal forest of Northeast China. Global Change Biology, 18: 2041-2056.

Mendonça, F.; Danni-Oliveira, I.M. 2007. Climatologia: noçôes básicas e climas do Brasil. Oficina de Texto, São Paulo. 206p.

Null, J. 2016. El Niño and La Niña Years and Intensities (http:// ggweather.com/enso/oni.htm). Acessed on 01/11/2017.

NWCG. 2017. National Wildfire Coordinating Group. Glossary $A-Z$ (https://www.nwcg.gov/glossary/a-z\#letter_w). Accessed on $01 / 03 / 2017$.

Oliveira, D.S.; Batista, A.C.; Soares, R.V.; Grodzki, L.; Vosgerau, J. 2004. Zoneamento de risco de incêndios florestais para o Estado do Paraná. Floresta, 34: 217-221.

Page, Y.L.; Pereira, J.M.C.; Trigo, R.; Camara, C.D.; Oom, D.; Mota, B. 2008. Global fire activity patterns (1996-2006) and climatic influence: an analysis using the World Fire Atlas. Atmospheric Chemistry and Physics, 8: 1911-1924.

Pereira, A.A., Pereira, J.A.A.; Morelli, F.; Barros, D.A.; Acerbi Junior, F.W.; Scolforo, J.R.S. 2012. Validação de focos de calor utilizados no monitoramento orbital de queimadas por meio de imagens TM. CERNE, 18: 335-343.

Primack, R.B.; Rodrigues, E. 2001. Biologia da conservaçâo. Midiograf, Londrina, 327p.

Schroeder, M.J.; Buck, C.C. 1970. Fire weather: a guide for application of meteorological information to forest fire control operations. USDA Forest Service, Agriculture Handbook 360, 229p.

SEMA. 2017. Secretaria do Estado do Meio Ambiente. Secretarias (http://www.amazonas.am.gov.br/entidade/secretatia-de-estadodo-meio-ambiente-sema/). Accessed on 01/02/2017.

Setzer, A.; Pereira, M.C.; Pereira Jr, A.C. 1992. O uso de satélites NOAA na detecção de queimadas no Brasil. Climanálise, 7: 40-53.

Shlisky, A.; Alencar, A.A.; Nolasco, M.M.; Curran, L.M. 2009. Overview: Global fire regime conditions, threats, and opportunities for fire management in the tropics. In: Cochrane, M.A. (Ed.). Tropical fire ecology: climate change, land use and ecosystem dynamics. Springer Praxis Books, Heidelberg, p.65-83. 
Soares, R.V.; Batista, A.C. 2007. Incêndios Florestais: controle, efeitos e uso do fogo. Universidade Federal do Paraná, Curitiba, 264p.

Sumila, T.C.A. 2016. Fontes e destinos de vapor de água na Amazônia e os efeitos do desmatamento. Master's thesis, Universidade Federal de Viçosa, Minas Gerais, 57p.

Suryabhagavan, K.V.; Alemu, M.; Balakrishnan, M. 2016. GISbased multi-criteria decision analysis for forest fire susceptibility mapping: a case study in Harenna forest, southwestern Ethiopia. Tropical Ecology, 57: 33-43.

Trenberth, K.E. 1997. The definition of El Niño. Bulletin of the American Meteorological Society, 78: 2771-2777.

Vasconcelos, S.S.; Fearnside, P.M.; Alencastro Graça, P.M.L.; Nogueira, E.M.; Oliveira, L.C.; Figueiredo, E.O. 2013. Forest fires in southwestern Brazilian Amazonia: Estimates of area and potential carbon emissions. Forest Ecology and Management, 291: 199-208.

Victoria, R.L.; Martinelli, L.A.; Moraes, J.M.; Ballester, M.V.; Krusche, A.V.; Pellegrino, G.; Richey, J.E. 1998. Surface air temperature variations in the Amazon region and its borders during this century. Journal of Climate, 11: 1105-1110.

Wang, S.D.; Miao, L.L.; Peng, G.X. 2012. An Improved Algorithm for Forest Fire Detection Using HJ Data. Procedia Environmental Sciences, 13: 140-150.
White, B.L.A. 2017. Satellite Detection of Wildland Fire in South America. Proceedings of the $2^{\text {nd }}$ World Congress on Civil, Structural, and Environmental Engineering. International Academy of Science, Engineering and Technology, Barcelona, Spain, paper ICESDP 111. doi: 10.11159/icesdp17.111

White, B.L.A.; Ribeiro, A.S. 2011. Análise da precipitação e sua influência na ocorrência de incêndios florestais no Parque Nacional Serra de Itabaiana, Sergipe, Brasil. Ambiente e Água, 6: $148-156$.

White, B.L.A.; White, L.A.S. 2016. Queimadas e incêndios florestais no estado de Sergipe, Brasil, entre 1999 e 2015. Floresta, 46: 561-570.

White, L.A.S.; White, B.L.A.; Ribeiro, G.T. 2016a. Modelagem especial do risco de incêndio florestal para o município de Inhambupe, BA. Pesquisa Florestal Brasileira, 36: 41-49.

White, B.L.A.; White, L.A.S.; Ribeiro, G.T.; Souza, R.M. 2016b. Empirical models for describing fire behavior in Brazilian commercial eucalypt plantations. CERNE, 22: 397-406.

RECEIVED: 03/01/2018

ACCEPTED: 04/08/2018

ASSOCIATE EDITOR: Gilberto Fisch 